UDC 33.021[657.411.005.5]

DOI: $10.15673 /$ fie.v13i3.2133

Vaskovska K.

PhD., Associate Professor

Department of Accounting and Auditing

E-mail: v.caterin17@gmail.com

ORCID ID: 0000-0001-8093-170X
Yevtushevska 0.

PhD, Associate Professor

Department of Accounting and Auditing

E-mail: olga163alex@gmail.com

ORCID ID: 0000-0003-4869-5123

\author{
Kirvas I. \\ Undergraduate \\ Department of Accounting and Auditing \\ Odessa National Academy of Food Technologies \\ Kanatna str., 112, Odesa, Ukraine, 65039 \\ E-mail: irakirvas78@gmail.com \\ ORCID ID: 0000-0001-6246-2700
}

\title{
INNOVATIVE ACTIVITY OF THE ENTERPRISE IN THE CONTEXT OF IMPROVING THE COST MANAGEMENT MECHANISM
}

Effective enterprise management is impossible without rational planning and control of costs. The relevance of the topic is due to the fact that the introduction of an effective cost management mechanism in the enterprise is a time-consuming process that requires professional knowledge in enterprise management. Proper cost management allows you to expand the boundaries of the business, allows the company to find additional sources of resources, make its products more attractive to consumers and expand market share, to win additional market segments. Being in constant interaction with a large number of suppliers, partners and consumers, it is necessary to use different models of cost reduction depending on the situation in the enterprise. And each company individually chooses the most effective methods of cost optimization.

The article presents and considers the features and methods of improving the cost management process in the food industry by implementing various types of innovations. The stages of the cost management process and the features of cost accounting have been identified. The main problems that food industry enterprises may face in cost accounting have been highlighted and recommendations have been given to prevent and eliminate these situations. Methods of cost reduction at enterprises have been proposed. The method of obtaining a positive economic effect on enterprises from the introduction of product, technological and organizational innovations has been considered. The introduction of different types of innovations is an integral part of management in the enterprise, as skillful cost management together with novelty gives a double economic effect. The reasons for overspending and a list of measures to minimize them have been given.

Key words: costs, innovation, accounting, resources, management, planning.

This work is licensed under a Creative Commons Attribution 4.0 International License http://creativecommons.org/licenses/by/4.0/

Statement of the problem and its connection with important scientific and practical tasks. Costs are one of the most important components of the production complex of the enterprise, because they affect the processes of pricing and profit. Currently, there is a significant increase in costs of the food industry, due to the rapid increase in the cost of production resources and obtaining unfavorable lending conditions, as a result of which the future development of the enterprise begins to depend on the degree of cost control. With this development of market relations, enterprises need to improve the cost management system to increase the competitiveness and profitability of all financial and economic activities of the enterprise.

Proper cost management allows you to expand the boundaries of the business, allows the company to find additional sources of resources, make its products more attractive to consumers and expand market share, to win additional market segments.

The analysis of the latest publications on the problem. A large number of scientific articles and publications by authors such as V.M. Panasyuk, O.O. Pilipenko, I.E. Davidovich, F.F. Butynets, O.V. Krushelnytska, S.F. Golov, I.A. Blank and others are devoted to the theory of the problem of cost planning in the enterprise, as well as cost management,

Examining the costs, such domestic and foreign scientists as S.F. Golov, L.V. Napadovska, V.M Panasyuk, O. Popov, say: the real direction of reducing costs is their management system [15].

According to many experts in this field, the criterion for the effectiveness of cost management is to reduce the cost of products. However, I.A. Blank notes that "reducing the level of cost is an important task, but not 
the main purpose of cost management, as it may be accompanied by a decrease in product quality and customer service" [2]. Thus, from this point of view, you can define cost management as the ability to save resources and maximize returns on them.

Given the position of domestic and foreign economists, cost management includes:

- information on the formation of costs; cost behavior;

- knowledge of the features and patterns of

- forecasting and planning of additional resources necessary for the successful development of the organization;

- ensuring a high degree of return on resource use $[14,17]$.

Paying tribute to the significant achievements of these authors, some issues of organization of control and cost management in the enterprise remain insufficiently disclosed and need further improvement.

Forming of the aims of the research. The purpose of this research is to improve the process of cost management in the food industry through the introduction of various types of innovations. To achieve this goal, it is necessary to consider the main problems associated with accounting and cost planning, to establish the economic effect of innovation and methods to improve cost management.

Giving an account of the main results and their substantiation. The introduction of an effective cost management mechanism in the food industry is a time-consuming process that requires professional knowledge in the field of enterprise management, taking into account the specifics of its activities. The process of cost management, for more efficient work, it is advisable to divide into several main stages (Fig. 1), at each of which you can assess the degree of its implementation and evaluate the work of cost management.

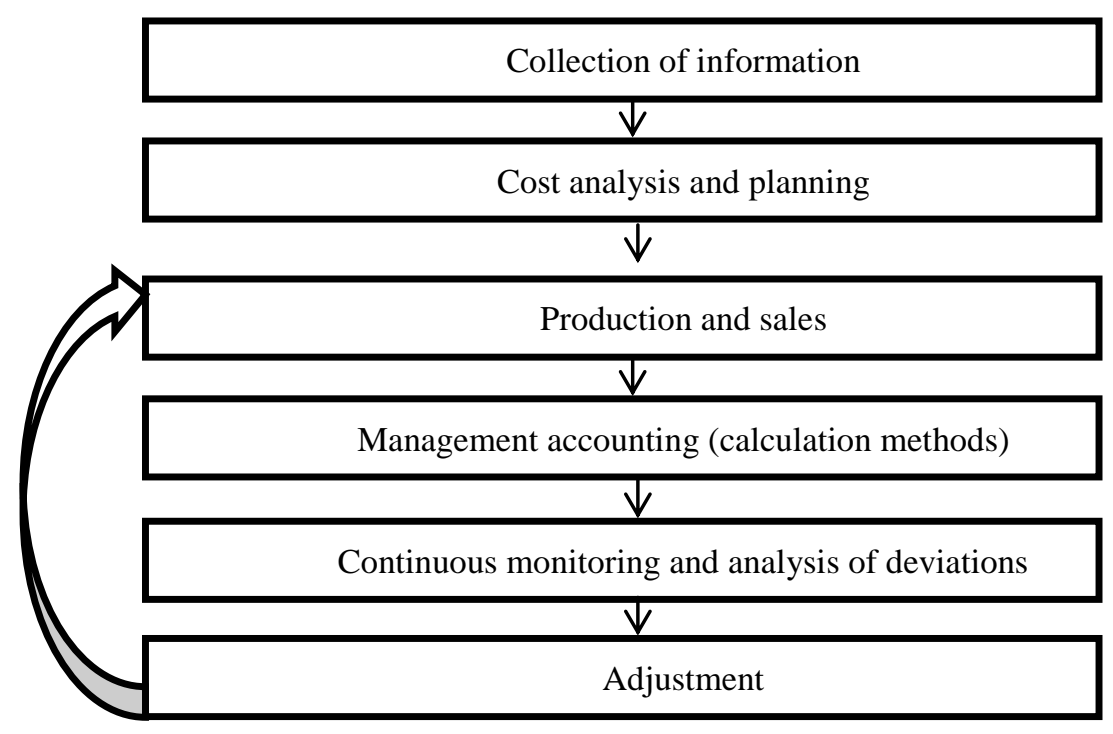

Fig. 1. Stages of cost management *

*compiled by the author on the basis of analysis of sources $[3,6]$

One of the main elements of cost management is cost planning. Cost planning is to determine the amount of costs required for production in a certain amount, as well as the cost of transportation, delivery, storage, maintenance, advertising. Planning is a way to control the rational use of resources [1].

The main features of costs that complicate their management in the enterprise are: dynamism (to reflect the real state of costs it is recommended to conduct their continuous analysis), diversity (companies need additional study of classification features of costs to assess the impact of various costs on economic activity), costs measurement complexity (because there are no absolutely accurate methods for measuring them), as well as the inconsistency of the impact on the economic result (the level of impact of costs on the amount of accounting profit is determined by the method of their accounting).

Lack of experience in the field of cost management leads the organization to the loss of benchmarks in the field of cost planning, loss of control over their level. Therefore, the problem of planning and cost management is quite relevant.

The main problems of imperfection of cost accounting used in the food industry are:

1. The problem of cost rationalization. Even with the most careful control over the level of costs in enterprises, it is not always possible to avoid inappropriate spending of resources. To prevent and avoid this situation, it is necessary to adjust standards and outdated technical standards. To optimize production parameters, it is recommended to implement automated cost management systems or automation of a specific business process, which can save labor, material and financial resources, reduce risks and obtain better information from various sources by processing large amounts of information.

2. Incomplete information and lack of skills to work with such information. When planning costs use data from previous periods, but the company may not 
have all the necessary information for the correct preparation of the cost plan. In this situation, the quality of planning decisions on costs will depend on the professionalism and competence of planners. Therefore, it is desirable for management not only to improve planning, but also to be able to take into account long-term forecasts despite their ambiguity and incompleteness.

3. Use of outdated accounting models. When planning costs, traditional accounting options are often preferred, despite the existence of alternative solutions. Outdated methods of cost accounting and product costing are often imperfect, and the methods used to regulate costs by foreign companies are not adapted to the conditions of specific Ukrainian companies. It follows that the most appropriate solution in this matter will be to create its own cost accounting system, with a specific classification of costs for a particular company and their details, which will take into account the specifics of its activities and identify reserves to minimize costs.

4. The problem of cost control at all levels of costs. Responsibility for the occurrence and implementation of costs should be assigned to employees of the enterprise, and not only to the management of the enterprise.

5. The problem of cost planning strategy. Goal setting in the process of choosing a cost planning strategy in many companies is very formalized, so the cost planning process is not clear enough. At the same time, enterprises do not have a sufficient link between operational and strategic cost planning. As a result of the above factors the implementation of the goals of the enterprise is complicated [5].

Usually cost management results in reducing them. The form of cost optimization is the use of operating lever (leverage). Its essence is to manage the ratio between fixed and variable costs, when not only the latter are optimized, but also gross profit is maximized. Businesses with a lower share of fixed costs reach break-even point earlier than competitors. At the same time, with the future increase in sales, enterprises with a lower share of variable costs will have an advantage in the form of a large share of profit in product growth [10].

One of the ways to reduce costs in the enterprise is the introduction of various types of innovations. Depending on the content and scope of applications innovations are divided into product, technological and organizational. Let's consider in more detail the features of each type of innovation.

Product innovations. When deciding on the introduction of a new product into production, first of all, the level of compliance with the requirements of competitiveness and profitability of production is assessed. Projects are selected that will provide better quality at a lower price. Specific ways to reduce the cost of new products for enterprises in different industries are different, but the main methods are: the use of cheaper raw materials (usually the replacement of imported raw materials with domestic, while for maintaining quality at the appropriate level special technologies are introduced to improve domestic raw materials), search for cheaper production technologies, resources saving, increasing of production rates.

Technological and technical innovations. Introduction of new technologies in production at many enterprises provides improvement of quality of production, increase of production volumes, maintenance of observance of ecological norms of production, improvement of working conditions, resource saving, economy of energy, water, raw materials, reduction of losses.

A set of innovations aimed at upgrading of equipment allows to increase the efficiency of raw materials, application while reducing energy costs.

The introduction of new technologies affects the improvement of the environmental situation at the enterprise. There is an obvious benefit from the introduction of such innovations by reducing fines for environmental pollution and reducing funds for the maintenance of treatment facilities.

At the same time, the improvement of working conditions also has a positive effect on the savings of the enterprise, because:

- allows you to reduce the percentage of product shortages;

- provides an increase in human performance as a result of reducing fatigue caused by unsatisfactory working conditions;

- provides an increase in the efficiency of the working time fund as a result of reducing all-day losses due to temporary incapacity for work due to illness and injury associated with adverse working conditions;

- allows to reduce material consequences from accidents and morbidity caused by production;

- reduces the cost of labor turnover caused by unsatisfactory working conditions.

Organizational innovations. Organizational innovations are aimed at increasing the centralization of company management, reducing the number of management units, reducing the cost of the enterprise for the purchase of raw materials and more.

The introduction of organizational innovations in the supply of raw materials allows to reduce costs by centralizing the process and increasing the size of the parties of procurement of materials and components.

Centralization of management allows you to direct the accumulated funds for the development of the enterprise, to pursue a common technical policy. One of the means of centralization of management is the restructuring of the main production, the creation of subsidiaries on the basis of the shops of the main production. Restructuring of enterprises, as a rule, involves a reduction in the number of employees, mainly managers at all levels. Optimization of management costs is of great importance, as the growth of the latter is one of the manifestations of bureaucratization of the enterprise, and this reduces its competitive position. To prevent the growth of the number of management staff, the company can determine the relative standards of the number of managers, standards for the cost of their maintenance and continue to comply with them. This applies, for example, to the share of managers' salaries in the total salary fund, the share of the 
number of managers in the total staff, the amount of revenue per manager, and so on.

It is also necessary to implement measures related to the prevention of overspending (constant analysis and control of costs, continuous strengthening of consumption of raw materials and materials, the establishment of potential areas with the highest risk of overspending). In order to prevent overspending, it is necessary to determine their possible causes. These may include: purchase of products with consumer properties below expectations, higher investment projects, forced use of loans and loans with unfavorable conditions, increase in the initial cost of purchased raw materials, inefficient use of equipment, financial omissions and abuse of managers, violations of laws, regulations and penalties sanctions, undesirable changes in legislation and regulations, inflation processes, negative changes in exchange rates, etc.

Conclusions and prospects of the further investigations. Based on the materials of this study, we can conclude that a well-thought-out cost management system in the food industry should promote a systematic approach to cost accounting, increase in the interest of all divisions in reducing costs, applying effective cost reduction methods and preventing possible overspending.

Recently, the importance of innovation for the development of food industry enterprises is growing significantly. The introduction of different types of innovations is an integral part of management in the enterprise, as skillful cost management together with novelty gives a double economic effect.

Enterprise cost management is an integral part of the enterprise management system as a whole. Only a comprehensive approach will effectively manage costs. Being in constant interaction with a large number of suppliers, partners and consumers, it is necessary to use different models of cost reduction depending on the situation in the enterprise. And each company individually chooses the most effective methods of cost optimization.

\section{References}

KNEU.

1. Bielov, M. A., Yevdokymova, N. M., \& Moskaliuk, V. Ye. (2002). Planuvannia diialnosti pidpryiemstva.

2. Blank, I. A. (2007). Upravlenie pribyilyu (3rd ed.). Nika-Tsentr.

3. Holov, S. F. (2003). Upravlinskyi oblik. Libra.

4. Davydovych, I. Ye. (2008). Upravlinnia vytratamy. Tsentr uchbovoi literatury.

5. Zhukova, Ye. A., \& Rozhkova, M. H. (2017). Problemy upravlinnia vytratamy na pidpryiemstvakh. Molodyi vchenyi, (12), 283-286. (5), 32-35

6. Kalienina, N. V. (2007). Metody upravlinnia vytratamy, yikh perevahy ta nedoliky. Derzhava ta rehiony,

7. Krushelnytska, O. V. (2010). Udoskonalennia systemy upravlinnia vytratamy na pidpryiemstvakh. Visnyk ZhDTU, (1), 125-129.

8. Leha, O. V., \& Yaloveha L.V. (2016). Upravlinskyi oblik vytrat vyrobnytstva v umovakh avtomatyzovanoi obrobky informatsii. Aktualni problemy innovatsiinoi ekonomiky, (2), 75-80.

9. Luchyk, S. D. (2014). Osoblyvosti avtomatyzatsii obliku vytrat vyrobnytstva. Bukhhalterskyi oblik, analiz $i$ audit, (4), 209-217.

10. Makarov, K. H. (2001). Leverydzh yak pokaznyk stiikosti vyrobnycho-ekonomichnykh system. Sotsialnoekonomichni doslidzhennia u perekhidnyi period. Ekonomichni problemy rozvytku vyrobnytstva rehionu, (31), 514-524.

11. Napadovska, L. V. (2000). Upravlinskyi oblik. Nauka i osvita.

12. Olinichenko, K. S. (2007). Ekonomichni aspekty evoliutsii pohliadiv na upravlinnia vytratamy. Visnyk Mizhnarodnoho slov'ianskoho universytetu, (1), 37-39.

13. Panasiuk, V. M. (2005). Vytraty vyrobnytstva: upravlinskyi aspekt. Aston.

14. Pylypenko, O. O. (2012). Upravlinnia vytratamy na suchasnykh pidpryiemstvakh. Formuvannia rynkovykh vidnosyn v Ukraini, (12), 8-9.

15. Popov, O. (2002). Upravlinnia vytratamy. Ekonomichna entsyklopediia. Vydavnychyi tsentr «Akademiia».

16. Tsal-Tsalko, Yu. S. (2002). Vytraty pidpryiemstva. TsUL.

17. Yasinska, A. I. (2007). Sutnist upravlinnia vytratamy na vitchyznianykh pidpryiemstvakh. Visnyk Natsionalnoho universytetu Lvivska politekhnika, (594), 357-360.

18. Barnes, N. M. (1977). Costmodeling - an integrated approach to planning and costcontrol. Engineering and Process Economics, (2), 24-51. doi: 10.1016/0377-841X(77)90058-4 Prentice-Hall.

19. Horngreen, C. T, Foster, G., \& Srikant, M. D. (1990). Cost accounting: a managerial emphasis (7th ed.).

20. Krieger, J. (1997). Establishing activity - based costing: Lessons and Pitfalls. Newspaper Financial Executives Quarterly, (3(4)), 14-17.

Received 6 August 2021

Approved 20 August 2021

Available in Internet 24.10.2021 


\author{
Васьковська К.О. \\ кандидат економічних наук, доцент \\ кафредра обліку та аудиту \\ E-mail: v.caterin17@gmail.com \\ ORCID ID: 0000-0001-8093-170X
}

\author{
Євтушевська 0.0. \\ кандидат економічних наук, доцент \\ кафедра обліку та аудиту \\ E-mail: olga163alex@gmail.com \\ ORCID ID: 0000-0003-4869-5123
}

\author{
Кірвас І.В. \\ магістрант \\ кафедра обліку та аудиту \\ Одеська національна академія харчових технологій \\ вул. Канатна 112, м. Одеса, Україна, 65039 \\ E-mail: irakirvas78@gmail.com \\ ORCID ID: 0000-0001-6246-2700

\section{ІННОВАЦІЙНА ДІЯЛЬНІСТЬ ПІДПРИЕМСТВА В КОНТЕКСТІ УДОСКОНАЛЕННЯ МЕХАНІЗМУ УПРАВЛІННЯ ВИТРАТАМИ}

Ефективне управління підприємством неможливе без раціонального планування та контролю витрат. Актуальність теми обумовлена тим, що впровадження ефективного механізму управління витратами на підприємстві є трудомістким процесом, що вимагає професійних знань з управління підприємством з урахуванням специфіки його діяльності.

Правильне управління витратами дозволяє розширити межі бізнесу, дозволяє компанії знайти додаткові джерела ресурсів, зробити свою продукцію більш привабливою для споживачів та розширити частку ринку, завоювати додаткові сегменти ринку. Добре продумана система управління витратами на підприємствах харчової промисловості має сприяти впровадженню системного підходу до обліку витрат, збільшити зацікавленість усіх підрозділів у скороченні витрат, застосуванні ефективних методів скорочення витрат та запобігання можливим перевитратам.

Знаходячись у постійній взаємодії з великою кількістю постачальників, партнерів та споживачів, необхідно використовувати різні моделі зниження витрат залежно від ситуації на підприємстві. I кожна компанія окремо вибирає найбільш ефективні методи оптимізації витрат.

У статті представлено та розглянуто особливості та методи вдосконалення процесу управління витратами в харчовій промисловості шляхом впровадження різних видів інновацій. Визначено етапи процесу управління витратами та особливості обліку витрат. Виділено основні проблеми, з якими можуть зіткнутися підприємства харчової промисловості при обліку витрат та надано рекомендації для попередження та усунення даних ситуацій. Запропоновано методи зниження витрат на підприємстві. Розглянуто спосіб отримання позитивного економічного ефекту на підприємствах від впровадження продуктових, технологічних та організаційних інновацій. Впровадження різних видів інновацій $є$ невід'ємною частиною управління на підприємстві, оскільки вміле управління витратами разом з новизною дає подвійний економічний ефект. Наведено причини перевитрат та перелік заходів щодо їх мінімізації.

Ключові слова: витрати, інноваційна діяльність, облік, ресурси, управління, планування.

\title{
Література
}

1. Бєлов М.А., Свдокимова Н.М., Москалюк В.Є. Планування діяльності підприємства: навчальний посібник. КНЕУ, 2002. $252 \mathrm{c}$.

2. Бланк И.А. Управление прибылью. 3-е изд., перераб. и доп. К.: Ника-Центр, 2007. 752 с.

3. Голов С.Ф. Управлінський облік: підручник. Київ: Лібра, 2003.704 с.

4. Давидович І.Є. Управління витратами: навч. посібник. Київ: Центр учбової літератури, 2008. 320 с.

5. Жукова Є.А., Рожкова М.Г. Проблеми управління витратами на підприємствах // Молодий вчений. 2017. № 12. C. 283-286.

6. Кальєніна Н.В. Методи управління витратами, їх переваги та недоліки // Держава та регіони. 2007. № 5. C. $32-35$

7. Крушельницька О.В. Удосконалення системи управління витратами на підприємствах // Вісник ЖДТУ. 2010. № 1. С. 125-129.

8. Лега О.В., Яловега Л.В. Управлінський облік витрат виробництва в умовах автоматизованої обробки інформації // Актуальні проблеми інноваційної економіки. 2016. №2. С. 75-80. 
9. Лучик С.Д. Особливості автоматизації обліку витрат виробництва // Бухгалтерський облік, аналіз і аудит. 2014. №4. С. 209-217.

10. Макаров К.Г. Леверидж як показник стійкості виробничо-економічних систем. Соціальноекономічні дослідження у перехідний період // Економічні проблеми розвитку виробництва регіону. № 31. Львів, ІРД НАН України 2001. С. 514-524.

11. Нападовська Л.В. Управлінський облік: монографія. Дніпропетровськ: Наука і освіта, 2000.450 с

12. Олініченко К.С. Економічні аспекти еволюції поглядів на управління витратами // Вісник Міжнародного слов'янського університету. Сер. Економічні науки. 2007. № 1. С. 37-39.

13. Панасюк В.М. Витрати виробництва: управлінський аспект. Тернопіль: Астон, 2005. 288 с.

14. Пилипенко О.О. Управління витратами на сучасних підприємствах // Формування ринкових відносин в Україні. 2012. № 12. С. 8-9.

15. Попов О. Управління витратами. Економічна енциклопедія: Київ: Видавничий центр «Академія», 2002. $952 \mathrm{c}$

16. Цал-Цалко Ю.С. Витрати підприємства: навч. посібник. К.: ЦУЛ, 2008. 656 с.

17. Ясінська А. І. Сутність управління витратами на вітчизняних підприємствах // Вісник Національного університету Львівська політехніка. № 594. 2007. С. 357-360.

18. Barnes N.M. Costmodeling - an integrated approach to planning and costcontrol // Engineering and Process Economics, 1977. №2, P. 24-51. doi: 10.1016/0377-841X(77)90058-4

19. Horngreen C.T, Foster G., Srikant M.D. Cost accounting: a managerial emphasis. 7th ed. Englewood: Prentice-Hall.1990

20. Krieger J. Establishing activity - based costing: Lessons and Pitfalls // Newspaper Financial Executives Quarterly. 1997. № 3(4), P.14-17.

Стаття надійшла 6.08.2021

Стаття прийнята до друку 20.08.2021

Доступно в мережі Internet 24.10.2021

Цитування згідно ДСТУ 8302:2015

Vaskovska K., Yevtushevska O., Kirvas I. Innovative activity of the enterprise in the context of improving the cost management mechanism // Food Industry Economics. 2021. Vol.13, Issue 3. P. 64-69. doi: 10.15673/fie.v13i3.2133

Cite as APA style citation

Vaskovska, K., Yevtushevska, O., \& Kirvas, I. (2021). Innovative activity of the enterprise in the context of improving the cost management mechanism. Food Industry Economics, 13(3), 64-69. doi: 10.15673/fie.v13i3.2133 